University of Nebraska - Lincoln

DigitalCommons@University of Nebraska - Lincoln

Publications of the Research Compliance

Services Staff

Research Compliance Services

March 2007

\title{
Making Research Trustworthy for Native Americans
}

Daniel R. Vasgird

University of Nebraska - Lincoln, dvasgird2@unl.edu

Follow this and additional works at: https://digitalcommons.unl.edu/researchcompsvcspubs

Part of the Higher Education Administration Commons

Vasgird, Daniel R., "Making Research Trustworthy for Native Americans" (2007). Publications of the Research Compliance Services Staff. 3.

https://digitalcommons.unl.edu/researchcompsvcspubs/3

This Article is brought to you for free and open access by the Research Compliance Services at DigitalCommons@University of Nebraska - Lincoln. It has been accepted for inclusion in Publications of the Research Compliance Services Staff by an authorized administrator of DigitalCommons@University of Nebraska - Lincoln. 
Published in Journal of Empirical Research on Human Research Ethics 2:1 (March 2007), pp. 84-85. Copyright (C) 2007 Joan Sieber; published by the University of California Press. Used by permission. http://caliber.ucpress.net/loi/jer

\title{
Making Research Trustworthy for Native Americans
}

\author{
Author: Daniel Vasgird, University of Nebraska-Lincoln, dvasgird2@unl.edu \\ Goal: To learn what research approaches are considered respectful and \\ trustworthy by Native American populations.
}

Ethical and scientific justification. The Federal Regulations of human research and other ethical guidelines did not prepare us for what we have learned, by trial and error, about conducting research on Native American populations. If research with these populations is to be conducted validly and respectfully, the ground rules need to be learned inductively, and ideally shared with other investigators.

Ethical objections or barriers. Many Native Americans live on reservations where their tribe is a sovereign government. Researchers have to consider first gaining permission to conduct research on the reservation, usually by presenting the research to the tribal council and getting a resolution supporting the project. While some tribes have research ethics committees, many do not. Thus, the researcher also has the ethical obligation to help the tribes develop a system for reviewing the research for human participants protection.

Given the history of exploitation of American Indian tribes by the government (broken treaties, relocation programs, forced acculturation), there is a long-standing distrust of the federal government on reservations. This is particularly true with respect to research funded by government agencies and conducted by outsiders. Based on this, and broken promises by researchers who have come before, there is a healthy skepticism about why the data are being gathered and how they will be used. It is clear that research with indigenous communities needs to be based on collaboration, yet procedures that place the approval of final protocols with external agencies undermines this collaboration. For example, the UNL ethics committee requires the University logo on almost all informed consent forms. This suggests the University as the sole responsible entity, and hence arouses ill feelings in many Native American research participants.

Current problem solving. What has evolved is that the informed consent letters for Native American groups are allowed to have a more familiar symbol at the top of the letters, one that is approved by a local advisory board to represent the partnership between the Tribes and the University (e.g., a dream catcher for one tribe). When native field researchers are trained, this needs to be done in a style that accommodates the culture of the tribe. This means that internet training is definitely out (i.e., CITI), even when internet access is available. Face-to-face is the only way such training can occur effectively and respectfully, and it needs to be done with a great deal of respect and latitude for questioning.

The fundamental principles of informed consent, confidentiality, and other human research protections are consistent with Tribal customs and practices, but they need to be presented and reviewed in culturally-appropriate contexts. The University of Nebraska-Lincoln (UNL) has developed projects that address these ethical concerns by providing assurances concerning how the data will be used, and what will be written. The UNL re- 
quests that the Tribal Council appoint an advisory board for the research project. UNL researchers restrict access to the data to only the approved project personnel, and assure the tribes that no one will merge tribal data with other data to make comparisons across racial groups (for example, to suggest that some problems are more prevalent or severe among American Indians). They also assure the tribes that they will see the summary of the research first. Applied research reports, with lay presentations of data summaries in pie charts, bar charts and basic tables, are prepared for each reservation. These reports are presented to the Tribal Council and advisory board. Any research prepared for publication from the project is sent to the advisory board members for review prior to submission. If tribal advisory board members raise any issues about cultural appropriateness of the research, UNL researchers pledge to review it and respond, prior to submitting for publication.

Suggested empirical questions. Science is understood to be a cumulative endeavor that develops through a peer reviewed literature. In research on Native Americans, there is an incipient literature that emphasizes the importance of collaborative approaches between scientists and the communities they aspire to study (e.g., Noe, Manson, Croy, McGough, Henderson \& Buchwald, 2006; Mohatt \& Thomas, 2006). Yet, in much research in traditional cultures, each researcher or institution begins somewhat anew. It would be highly ethical and scientifically appropriate to begin to build a literature, in print and on line, fostering development of cumulative knowledge and expertise in this area. That literature should move beyond broad generalities to the specifics of what is appropriate.

1. What literature exists on effective and respectful research approaches with traditional populations within the North American continent? Is there a literature on which a review of that methodology could be based?

2. What questions have guided the University of Nebraska researchers, and others who have studied traditional populations within the North American continent, in their inductive learning of effective and respectful approaches? How might these questions be formulated more broadly to guide other researchers?

3. What organizations would be interested in pooling new information, perhaps via a list serve and updating an online manual as new methodology evolves?

\section{References}

American Indian Law Center (1999). Model tribal research code, with materials for tribal regulation for research and checklist for Indian health boards (3rd ed.). Albuquerque, NM: American Indian Law Center.

BALDWIN, J. (1999). Conducting drug abuse prevention research in partnership with Native American communities: Meeting challenges through collaborative approaches. Drugs and Society, 14, 77-92.

BEAUVAIS, F. (1999). Obtaining consent and other ethical issues in the conduct of research in American Indian communities. Drugs and Society, 14, 167-189.

FISHER, P. A.; BALL, T. J. (2003). Tribal participatory research: Mechanisms of a collaborative model. American Journal of Community Psychology, 32(3-4), 207-216.

FISHER, P. A.; BALL, T. J. (2002). The Indian family wellness project: An application of the tribal participatory research model. Prevention Science, 3(3), 235-240.

MOHATT, G. V. (1989). The community as informant or collaborator? American Indian \& Alaska Native Mental Health Research, 2, 64-70.

MOHATT, G. V. \& THOMAS, L. R. (2006). "I wonder, why would you did it that way?" Ethical dilemmas in doing participatory research with Alaska native communities. (Pp. 93-115) In J. Trimble, \& C. Fisher (eds.) The handbook of ethical research with ethnocultural populations and communities. Thousand Oaks: Sage.

MORAN, J. (1995). Culturally sensitive alcohol prevention research in ethnic communities. In P. Langton, L. Epstein, \& M. Orlandi, (Eds.), The challenge of participatory research: Preventing alcohol-related problems in the ethnic community. (Pp. 43-56). CSAP Cultural Competence Series 3, DHHS Publication No. SMA 95-3042). Washington, DC: U.S. Department of Health and Human Services.

NOE, T., MANSON, S., CROY, C., MCGOUGH, H., HENDERSON, J., \& BUCHWALD, D. (2006). In their own voices: American Indian decisions to participate in health research. (Pp. 77-92). In J. Trimble, \& C. Fisher (eds.) The handbook of ethical research with ethnocultural populations and communities. Thousand Oaks: Sage.

NORTON, I. M., \& MANSON, S. M. (1996). Research in American Indian and Alaska Native communities: Navigating the cultural universe of values and process. Journal of Consulting and Clinical Psychology, 64(5), 856-860.

STUBBEN, J. D. (2001). Working with and conducting research among American Indian families. American Behavioral Scientist, 44(9),1466-1481. 